\title{
Studi Kecepatan Aliran Air dengan Menggunakan Tabung Pitot
}

\author{
Muhammad Taufik Iqbal $^{1, \mathrm{a}}$ dan Zulvyah Faisal $^{1, \mathrm{~b}}$ \\ ${ }^{1}$ Jurusan Teknik Sipil, Politeknik Negeri Ujung Pandang, Makassar, 90245, Indonesia \\ ${ }^{a}$ muhtaufikiqbal@poliupg.ac.id \\ b zulvyahfaisal@poliupg.ac.id
}

\begin{abstract}
The tools and methods used in the measurement of water flow velocity are now very diverse, such as by using Venturi Meter, Orifice, Current Meter, Pitot Tube, and so forth. To learn more about water flow velocity measurement method, in order to improve professionalism in the field of water resources can be done research at Hydraulics Laboratory by researching Water Flow Analysis by Using Pitot Tubes. The research process will be carried out using three varied channel basis samples: reviewing the velocity of the water flow at the bottom of the channel with slippery base, reviewing the flow rate of the water on the gravel base channel, and reviewing the flow rate of the water on the channel with the decking concrete base. The expected result of this research is knowing the distribution of velocity in a cross section such as drainage channel, irrigation channel and river, so construction of water structure can be adjusted position placement in the open channel section. In addition it can be used as a reference in planning an open channel. One of the benefits to construction cofferdam construction speed distribution is to determine the dewatering system to be carried out during construction.
\end{abstract}

Keywords- Flow Speed, Speed Distribution. Channel Basic Variations

Abstrak- Alat dan metode yang digunakan dalam pengukuran kecepatan aliran air kini sudah sangat beragam, diantaranya yaitu dengan menggunakan Venturi Meter, Orifice, Current Meter, Pitot Tube, dan lain sebagainya. Untuk mempelajari lebih lanjut tentang metode pengukuran kecepatan aliran air, maka dalam rangka meningkatkan profesionalisme dalam bidang sumber daya air dapat dilakukan penelitian di Laboratorium Hidrolika dengan meneliti Analisa Kecepatan Aliran Air dengan Menggunakan Tabung Pitot. Proses penelitian yang akan dilakukan dengan menggunakan tiga sampel dasar saluran yang bervariasi yaitu : meninjau kecepatan aliran air pada dasar saluran dengan dasar licin, meninjau kecepatan aliran air pada saluran dengan dasar batu kerikil, dan meninjau kecepatan aliran air pada saluran dengan dasar beton decking. Hasil yang diharapkan dari penelitian ini adalah dengan diketahuinya distribusi kecepatan pada suatu penampang misalnya saluran drainase, saluran irigasi dan sungai maka konstruksi bangunan air dapat disesuaikan posisi penempatannya dalam penampang saluran terbuka tersebut. Selain itu dapat dijadikan referensi dalam merencanakan saluran terbuka. Salah satu manfaat pada pembangunan konstruksi cofferdam distribusi kecepatan sangat menentukan sistem dewatering yang akan dilakukan pada saat konstruksi.
Kata Kunci; Kecepatan Aliran, Distribusi Kecepatan. Variasi Dasar Saluran

\section{Pendahuluan}

Di era seperti sekarang ini, perkembangan ilmu pengetahuan di segala aspek kehidupan juga terus terjadi. Tidak terkecuali di dalam lingkup ketekniksipilan. Dalam pekerjaan teknik sipil, khususnya pada perencanaan bangunan keairan (hydrolic structure), pengukuran kecepatan aliran air merupakan salah satu bagian yang sangat penting. Karena penentuan kecepatan di sejumlah di suatu penampang memungkikan penentuan besarnya debit, maka pengukuran kecepatan merupakan suatu fase yang penting dalam pengukuran aliran. Kecepatan dapat diperoleh dengan mengukur waktu yang di perlukan suatu partikel yang dapat dikenali untuk bergerak sepanjang suatu jarak yang diketahui. Teknik ini telah dikembangkan guna mempelajari aliran di dalam daerah yang begitu kecilnya sehingga aliran normalnya akan sangat terganggu dan barangkali lenyap seandainya disisipkan instrumen untuk mengukur kecepatan. Harus disediakan daerah pengamatan yang tembus pandang.

Dengan adanya suatu permukaan bebas dan gesekan di sepanjang saluran maka kecepatan dalam saluran tidak terbagi merata dalam penampang saluran. Kecepatan maksimum dalam saluran biasanya terjadi di bawah permukaan bebas sedalam 0,05 sampai 0,25 kali kedalamannya, makin dekat ke tepi berarti makin dalam dan mencapai maksimum.

Gambar di bawah ini menggambarkan pola umum distribusi kecepatan pada berbagai penampang vertikal dan horizontal untuk saluran berpenampang persegi panjang dan kurva kecepatan yang sama pada penampang melintangnya. Distribusi kecepatan pada 
penampang saluran juga tergantung pada faktor-faktor lain, seperti bentuk penampang yang tidak lazim, kekasaran saluran dan adanya tekukan-tekukan. Pada arus yang lebar, deras dan dangkal atau saluran yang sangat licin kecepatan maksimum sering terjadi di permukaan bebas [2].
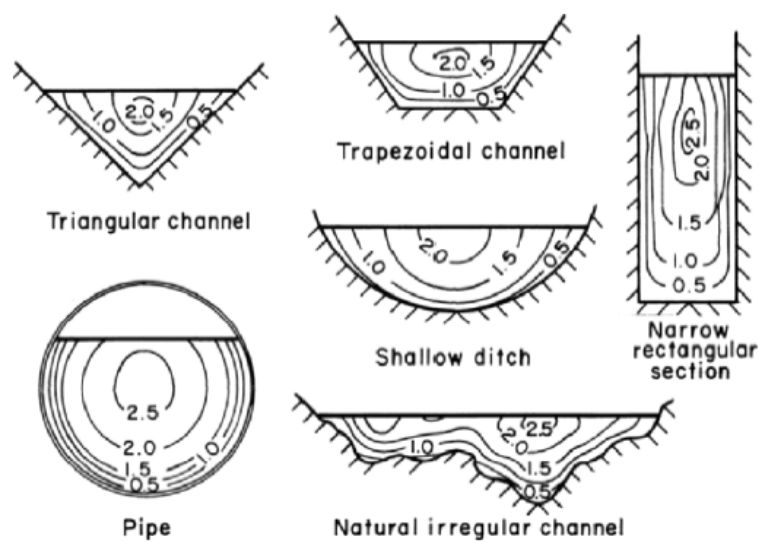

Gambar 1. Distibusi Kecepatan Pada Aliran

Parameter aliran seperti laju atau kecepatan, tekanan, temperatur, serta laju aliran volumetrik (debit) atau laju aliran massa [3], dalam suatu sistem fluida adalah hal yang perlu diketahui. Pengukuranpengukuran besaran ini antara lain diperlukan dalam :

1. Pengendalian proses manufakturing

2. Pengujian untuk kerja peralatan-peralatan seperti pompa, turbin, kipas, blower, baling-baling, dan aerofoil

3. Studi-studi hidrologi sehubungan dengan curah hujan, drainase daerah genangan air dan pembagian serta pengendalian air dalam sistemsistem irigasi

4. Penentuan harga apabila suatu fluida diperjualbelikan, misalnya air, gas, uap untuk proses atau pemanasan, dan bahan bakar cair

5. Kegiatan-kegiatan eksperimen dalam programprogram riset serta pengembangan.

Teknik-teknik pengukuran aliran fluida makin lama makin kompleks karena makin besarnya kebutuhan atas informasi yang lebih rinci serta karena diperlukannya pengukuran-pengukuran jarak jauh menggunakan teknik-teknik telemeter yang melibatkan metode-metode elektronik. Sistem-sistem pengukuran umumnya terdiri dari tiga bagian : alat sensor, medium atau sistem transmisi, dan alat penunjuk atau perekam [6].

Pengukuran aliran adalah sebuah ilmu yang membahas koefisien, karena kita umumnya menerapkan persamaan Bernoulli untuk aliran zat cair dan persamaan energi aliran steady untuk aliran gas isontropik (dalam masing-masing kasus fluida diandaikan tanpa gesekan) dan kemudian membandingkan perilaku fluida sejati (viskous) dengan fluida ideal melalui perbandingan koefisienkoefisien kecepatan atau debit [5],[7].

Alat yang dipergunakan tidak mengukur kecepatan secara langsung tetapi menghasilkan suatu besaran yang dapat diukur dan yang dapat dihubungkan dengan kecepatan [5]. Dalam gambar di bawah ini sebuah tabung kaca atau jarum suntik dengan belokan siku-siku dipergunakan untuk mengukur kecepatan $\mathrm{v}$ di dalam suatu saluran terbuka. Lubang tabung diarahkan ke hulu sehingga fluida mengalir ke dalam lubang tersebut sampai tekanan di dalam tabung meningkat secukupnya untuk menahan dampak kecepatan terhadapnya. Tepat di depan lubang tesebut fluida tidak bergerak. Garis-aliran yang melalui 1 melintas ke titik 2, yang disebut titik stagnasi, tempat fluida tidak bergerak, dan di sana bercabang serta melintas di sekitar tabung. Tekanan di 2 diketahui dari kolom cairan di dalam tabung [1], [2].

Tabung pitot mengukur tekanan stagnasi, yang juga disebut tekanan total. Tekanan total terdiri dari dua bagiaang dinyatakan dalam panjang kolom fluida yang mengalir. Tekanan dinamik dihubungkan dengan tinggn, yaitu tekanan statik $h_{0}$ dan tekanan dinamik $\Delta \mathrm{h}$, yi-kecepatan oleh persamaan di atas.

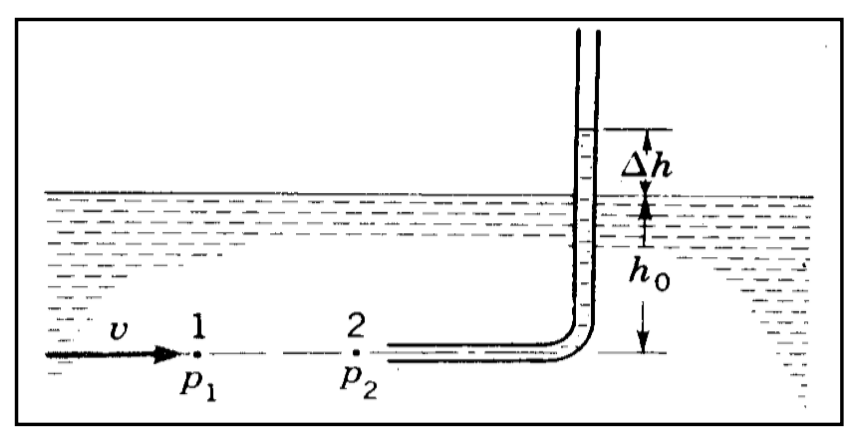

Gambar 2. Tabung pitot sederhana 


\section{Metode Penelitian}

Metode pengumpulan data dalam penelitian ini, yakni : Penelitian pustaka, dengan membaca sejumlah buku, literatur-literatur serta hasil-hasil penelitian terdahulu yang berkaitan dengan masalah perhitungan ini [3],[4].

Metode yang digunakan dalam penelitian ini adalah metode experimental laboratorium dengan menggunakan alat ukur tabung pitot untuk pengambilan data kecepatan.

1. Alat yang Digunakan

Alat dan bahan yang digunakan dalam praktikum ini adalah sebagai berikut : Tabung Pitot, manometer digital, stopwatch, alat tulis, karpet, batu kerikil 2/3 (seragam), beton decking (1:3), lem, hidrolyc bench, flume dan pompa.

Pada penelitian ini digunakan satu rangkaian simulator saluran terbuka (Open Channel) yang berbentuk persegi panjang yang berdimensi panjang : 4,9 cm, lebar dalam : 7,5 cm, lebar luar : $9,5 \mathrm{~cm}$, tinggi : $25 \mathrm{~cm}$, tebal $1 \mathrm{~cm}$. Saluran ini dilengkapi dengan bak penampungan air, bak pengaliran air, pengatur kemiringan serta pompa dengan katup pengatur volume air yang digunakan untuk menentukan debit air yang keluar dalam setia satuan waktu. Dimana asumsi dasar dalam pengujian ini, bahwa aliran yang akan diuji diasumsikan sebagai aliran seragam dimana luas penampang saluran dan ketinggian muka air cenderung tetap selama satu kali running pengaliran.

2. Adapun tahapan-tahapan pengambilan data sebagai berikut:

a. Membuat grid-grid sebagai titik fokus peletakan alat. Grid ini dibuat karena diketahui bahwa distribusi kecepatan aliran air pada profil melintang flume tidak seragam, antara bagian dasar saluran, tengah saluran dan permukaan saluran.

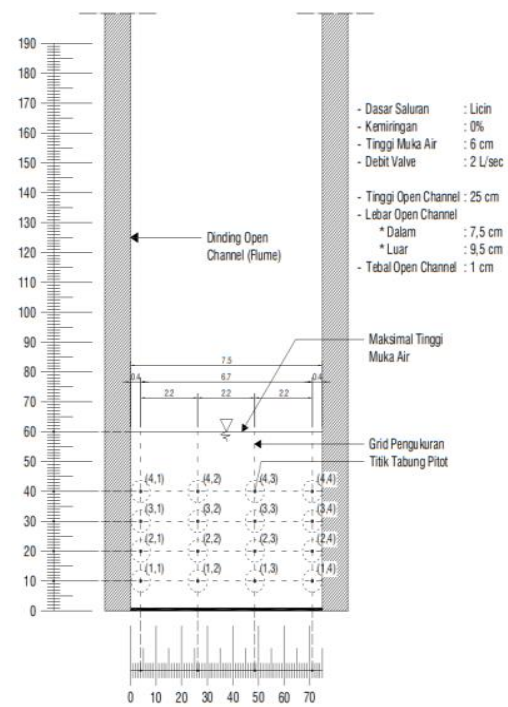

Gambar 3. Grid/titik fokus alat

b. Tabung Pitot diletakkan pada titik (1.1), (2.1), (3.1) dan seterusnya.

c. Menyalakan mesin pompa. Tunggu beberapa menit hingga aliran stabil. Sebelum melakukan pembacaan.

d. Pengukuran dan pengambilan data diulangi pada setiap kemiringan $0 \%, 1,5 \%$ dan $2,5 \%$. Penentuan kemiringan pada circulating flume dilakukan dengan sistem jacking yang berupa pemutar dengan kedua poros besi panjang pada section flume selanjutnya. Putaran ini mampu menaikkan dan murunkan ketinggian poros besi section circulating flume. Seperti pada gambar di bawah ini :

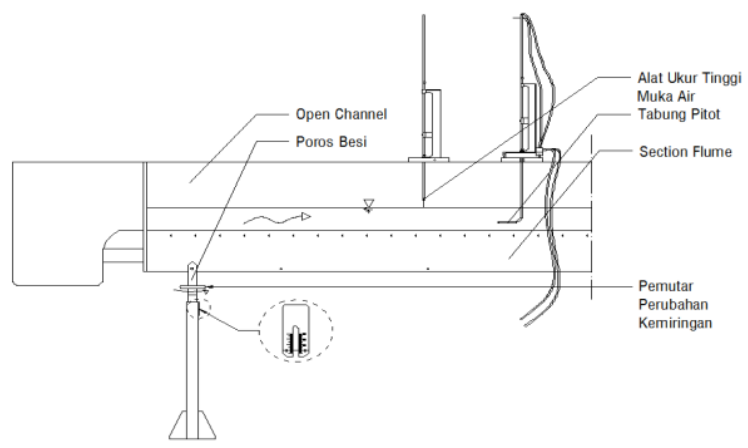

Gambar 4. Saluran Terbuka (Open channel)

e. Setiap titik dilakukan pembacaan sebanyak lima kali pengambilan data setiap satu menit. 
f. Pengambilan data tinggi muka air dan kecepatan aliran pada saluran terbuka dilakukan pada dasar saluran licin dan batu kerikil.

g. Analisa perhitungan data tinggi muka air dan kecepatan.

h. Membuat Grafik.

\section{Hasil dan Pembahasan}

A. Hasil

Setelah melakukan pengujian, diperoleh data seperti di bawah ini ::

1. Tiga Dimensi Aliran dengan Dasar Licin

a. Kemiringan $0 \%$

Tabel 1. Data hasil pengujian dengan dasar saluran licin

\begin{tabular}{|c|c|c|c|c|c|c|c|c|c|c|}
\hline \multirow{2}{*}{ No } & \multirow{2}{*}{$\begin{array}{l}\text { Titik } \\
\text { Grid }\end{array}$} & \multirow{2}{*}{$\begin{array}{c}\text { Kemiringan } \\
(\%)\end{array}$} & \multirow{2}{*}{$\begin{array}{c}\mathbf{V} \\
\text { (liter) }\end{array}$} & \multicolumn{6}{|c|}{$\Delta \mathbf{H}(\mathrm{mm})$} & \multirow{2}{*}{$\begin{array}{c}\text { Kecepatan di } \\
\text { titik Grid } \\
\text { (m/dtk) }\end{array}$} \\
\hline & & & & $\Delta \mathbf{H}_{1}$ & $\Delta \mathbf{H}_{2}$ & $\Delta \mathbf{H}_{3}$ & $\Delta \mathbf{H}_{4}$ & $\Delta \mathbf{H}_{5}$ & $\underset{\text { rata- }}{\Delta \mathbf{H}_{\text {Rata }}}$ & \\
\hline 1 & 1.1 & \multirow{16}{*}{$0 \%$} & \multirow{16}{*}{5} & 1,8 & 2,1 & 2,1 & 2,2 & 2 & 2,04 & 0,200 \\
\hline 2 & 1.2 & & & 2,5 & 2,4 & 2,5 & 2,7 & 2,6 & 2,54 & 0,223 \\
\hline 3 & 1.3 & & & 2,5 & 2,3 & 2,4 & 2,3 & 2,4 & 2,38 & 0,216 \\
\hline 4 & 1.4 & & & 2 & 1,8 & 1,9 & 1,9 & 2 & 1,92 & 0,194 \\
\hline 5 & 2.1 & & & 1,9 & 1,6 & 2,1 & 1,8 & 1,8 & 1,84 & 0,190 \\
\hline 6 & 2.2 & & & 2,4 & 2,5 & 2,4 & 2,5 & 2,5 & 2,46 & 0,220 \\
\hline 7 & 2.3 & & & 2,7 & 2,6 & 2,7 & 2,9 & 2,5 & 2,68 & 0,229 \\
\hline 8 & 2.4 & & & 2 & 1,8 & 1,9 & 2 & 2,1 & 1,96 & 0,196 \\
\hline 9 & 3.1 & & & 4,2 & 3,9 & 3,9 & 4 & 3,8 & 3,96 & 0,279 \\
\hline 10 & 3.2 & & & 4,6 & 4,6 & 4,4 & 4,6 & 4,5 & 4,54 & 0,298 \\
\hline 11 & 3.3 & & & 4,4 & 4,5 & 4,3 & 4,5 & 4,5 & 4,44 & 0,295 \\
\hline 12 & 3.4 & & & 4,3 & 4,3 & 4 & 4,2 & 4,2 & 4,2 & 0,287 \\
\hline 13 & 4.1 & & & 1,6 & 1,6 & 1,4 & 1,5 & 1,5 & 1,52 & 0,173 \\
\hline 14 & 4.2 & & & 1,7 & 1,8 & 1,7 & 1,7 & 1,5 & 1,68 & 0,182 \\
\hline 15 & 4.3 & & & 1,6 & 1,7 & 1,5 & 1,6 & 1,7 & 1,62 & 0,178 \\
\hline 16 & 4.4 & & & 1,4 & 1,3 & 1,4 & 1,5 & 1,6 & 1,44 & 0,168 \\
\hline
\end{tabular}

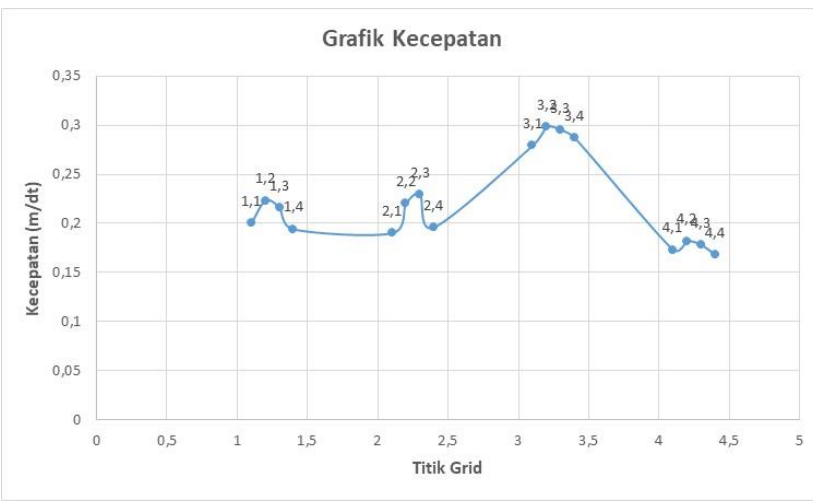

Gambar 5. Grafik kecepatan dasar saluran licin kemiringan $0 \%$
Dari grafik di atas dapat dilihat bahwa kecepatan aliran maksimum pada dasar saluran licin dengan kemiringan 0\% terletak pada titik grid 3.3 dengan kecepatan 0,298 m/dtk dengan volume 5 liter.

b. Kemiringan $1,5 \%$

Tabel 2. Data hasil pengujian dengan dasar saluran licin
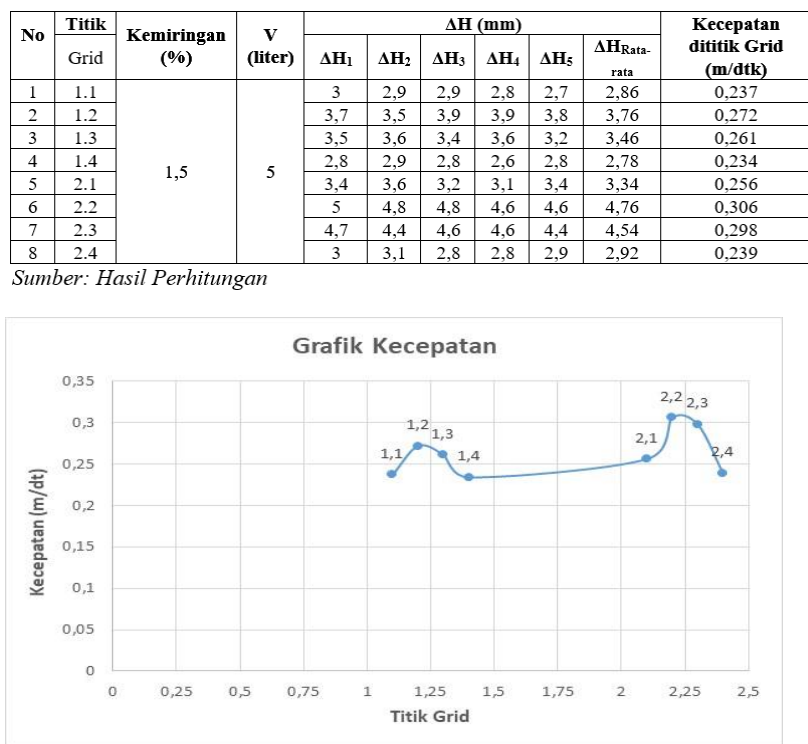

Gambar 6. Grafik kecepatan dasar saluran licin kemiringan $1,5 \%$

Dari grafik di atas dapat dilihat bahwa kecepatan aliran maksimum pada dasar saluran licin dengan kemiringan $0 \%$ terletak pada titik grid 2.2 dengan kecepatan $0,306 \mathrm{~m} / \mathrm{dtk}$ dengan volume 5 liter.

c. Kemiringan $2,5 \%$

Tabel 3. Data hasil pengujian dengan dasar saluran licin

\begin{tabular}{|c|c|c|c|c|c|c|c|c|c|c|}
\hline \multirow{2}{*}{ No } & \multirow{2}{*}{$\begin{array}{l}\text { Titik } \\
\text { Grid }\end{array}$} & \multirow{2}{*}{$\begin{array}{c}\text { Kemiringan } \\
(\%)\end{array}$} & \multirow{2}{*}{$\underset{\text { (liter) }}{\mathbf{V}}$} & \multicolumn{6}{|c|}{$\Delta \mathbf{H}(\mathrm{mm})$} & \multirow{2}{*}{$\begin{array}{c}\text { Kecepatan } \\
\text { dititik Grid } \\
\text { (m/dtk) }\end{array}$} \\
\hline & & & & $\Delta \mathbf{H}_{\mathbf{l}}$ & $\Delta \mathbf{H}_{2}$ & $\Delta \mathbf{H}_{3}$ & $\Delta \mathbf{H}_{4}$ & $\Delta \mathbf{H}_{5}$ & 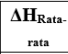 & \\
\hline 1 & 1.1 & \multirow{8}{*}{2,5} & \multirow{8}{*}{5} & 5 & 5,3 & 4,8 & 5,5 & 5,2 & 5,16 & 0,318 \\
\hline 2 & 1.2 & & & 6,7 & 6,5 & 6,5 & 6,7 & 6,6 & 6,6 & 0,360 \\
\hline 3 & 1.3 & & & 6 & 6,2 & 5,8 & 6,1 & 6,3 & 6,08 & 0,345 \\
\hline 4 & 1.4 & & & 4 & 3,8 & 3,9 & 4,2 & 4,3 & 4,04 & 0,282 \\
\hline 5 & 2.1 & & & 5,1 & 5,2 & 5,3 & 5,3 & 5,2 & 5,22 & 0,320 \\
\hline 6 & 2.2 & & & 6,8 & 6,9 & 6,7 & 6,7 & 6,9 & 6,8 & 0,365 \\
\hline 7 & 2.3 & & & 6,7 & 6,8 & 6,7 & 6,5 & 6,5 & 6,64 & 0,361 \\
\hline 8 & 2.4 & & & 4,6 & 4,3 & 4,5 & 4,6 & 4,6 & 4,52 & 0,298 \\
\hline
\end{tabular}




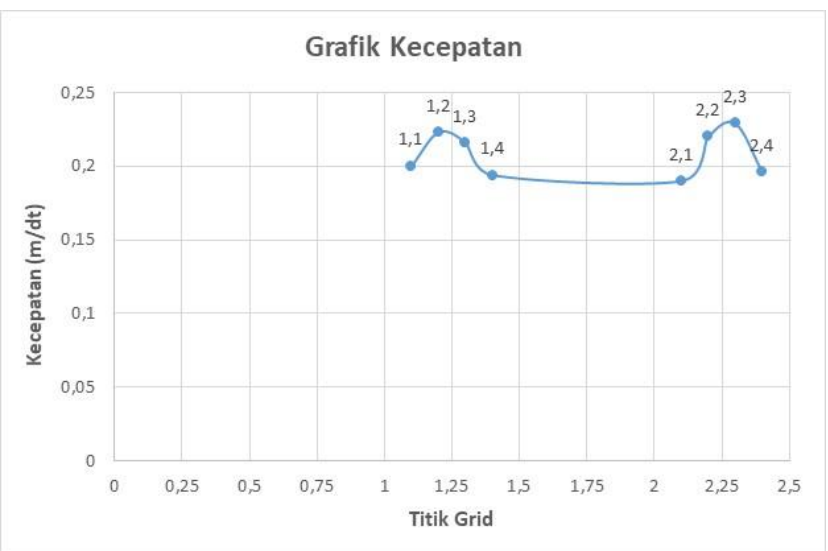

Gambar 7. Grafik kecepatan dasar saluran licin kemiringan $2,5 \%$

Dari grafik di atas dapat dilihat bahwa kecepatan aliran maksimum pada dasar saluran licin dengan kemiringan $0 \%$ terletak pada titik grid 2.2 dengan kecepatan 0,365 $\mathrm{m} / \mathrm{dtk}$ dengan volume 5 liter.

\section{Tiga Dimensi Aliran dengan Dasar Kerikil}

\section{a. Kemiringan $0 \%$}

Tabel 4. Data hasil pengujian dengan dasar saluran Kerikil

\begin{tabular}{|c|c|c|c|c|c|c|c|c|c|c|}
\hline \multirow[b]{2}{*}{ No } & \multirow{2}{*}{$\begin{array}{l}\text { Titik } \\
\text { Grid }\end{array}$} & \multirow{2}{*}{$\begin{array}{c}\text { Kemiringan } \\
(\%)\end{array}$} & \multirow{2}{*}{$\begin{array}{c}\mathbf{v} \\
\text { (liter) }\end{array}$} & \multicolumn{6}{|c|}{$\Delta \mathbf{H}(\mathbf{m m})$} & \multirow{2}{*}{$\begin{array}{c}\text { Kecepatan } \\
\text { dititik Grid } \\
\text { (m/dtk) }\end{array}$} \\
\hline & & & & $\Delta \mathbf{H}_{1}$ & $\Delta \mathbf{H}_{2}$ & $\Delta \mathbf{H}_{3}$ & $\Delta \mathbf{H}_{4}$ & $\Delta \mathbf{H}_{5}$ & $\underset{\text { Rata }}{\Delta \mathbf{H}_{\text {Rat }}}$ & \\
\hline 1 & 1.1 & \multirow{20}{*}{$0 \%$} & \multirow{20}{*}{5} & 0,5 & 0,5 & 0,6 & 0,5 & 0,6 & 0,54 & 0,103 \\
\hline 2 & 1.2 & & & 0,6 & 0,6 & 0,7 & 0,8 & 0,7 & 0,68 & 0,116 \\
\hline 3 & 1.3 & & & 0,7 & 0,8 & 0,9 & 0,9 & 0,8 & 0,82 & 0,127 \\
\hline 4 & 1.4 & & & 0,5 & 0,6 & 0,7 & 0,6 & 0,6 & 0,6 & 0,108 \\
\hline 5 & 2.1 & & & 1,1 & 1 & 1,2 & 1 & 1,1 & 1,08 & 0,146 \\
\hline 6 & 2.2 & & & 1,4 & 1,4 & 1,3 & 1,4 & 1,4 & 1,38 & 0,165 \\
\hline 7 & 2.3 & & & 1,5 & 1,6 & 1,5 & 1,3 & 1,5 & 1,48 & 0,170 \\
\hline 8 & 2.4 & & & 1,4 & 1,1 & 1,2 & 1,3 & 1,2 & 1,24 & 0,156 \\
\hline 9 & 3.1 & & & 0,9 & 1 & 0,7 & 1 & 1,1 & 0,94 & 0,136 \\
\hline 10 & 3.2 & & & 1,3 & 1,4 & 1,4 & 1,4 & 1,4 & 1,38 & 0,165 \\
\hline 11 & 3.3 & & & 1,6 & 1,5 & 1,6 & 1,4 & 1,5 & 1,52 & 0,173 \\
\hline 12 & 3.4 & & & 1 & 1,2 & 1,1 & 1,3 & 1,1 & 1,14 & 0,150 \\
\hline 13 & 4.1 & & & 1,1 & 1,2 & 1,2 & 1,1 & 1,2 & 1,16 & 0,151 \\
\hline 14 & 4.2 & & & 2 & 2 & 1,9 & 1,8 & 1,9 & 1,92 & 0,194 \\
\hline 15 & 4.3 & & & 2 & 2 & 1,8 & 2 & 2,1 & 1,98 & 0,197 \\
\hline 16 & 4.4 & & & 1,5 & 1,6 & 1,4 & 1,5 & 1,5 & 1,5 & 0,172 \\
\hline 17 & 5.1 & & & 1 & 1,1 & 0,9 & 1 & 0,8 & 0,96 & 0,137 \\
\hline 18 & 5.2 & & & 1,5 & 1,4 & 1,5 & 1,4 & 1,3 & 1,42 & 0,167 \\
\hline 19 & 5.3 & & & 1,5 & 1,6 & 1,5 & 1,6 & 1,7 & 1,58 & 0,176 \\
\hline 20 & 5.4 & & & 1,4 & 1,3 & 1,3 & 1,2 & 1,3 & 1,3 & 0,160 \\
\hline
\end{tabular}

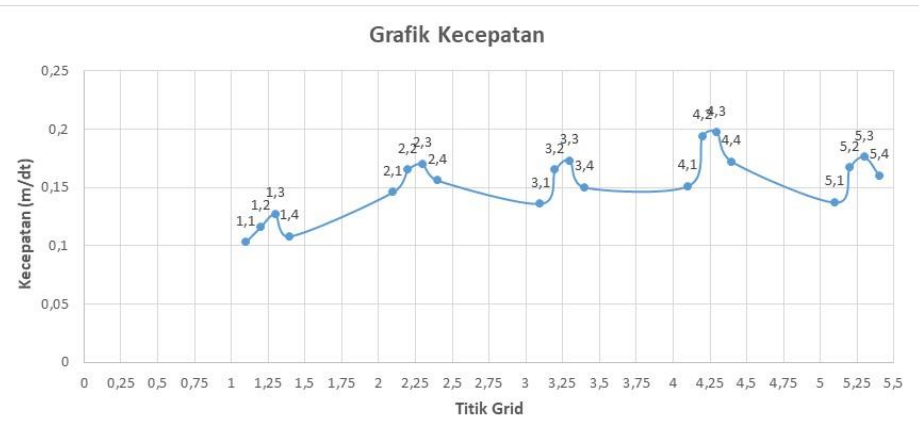

Gambar 8. Grafik kecepatan dasar saluran Kerikil kemiringan $0 \%$

Dari grafik di atas dapat dilihat bahwa kecepatan aliran maksimum pada dasar saluran kerikil dengan kemiringan 0\% teletak pada titik grid 4.3 dengan kecepatan 0,197 m/dtk dengan volume air 5 liter.

\section{b. Kemiringan $1,5 \%$}

Tabel 5. Data hasil pengujian dengan dasar saluran Kerikil

\begin{tabular}{|c|c|c|c|c|c|c|c|c|c|c|}
\hline \multirow{2}{*}{ No } & \multirow{2}{*}{$\begin{array}{l}\text { Titik } \\
\text { Grid }\end{array}$} & \multirow{2}{*}{$\begin{array}{c}\text { Kemiringan } \\
(\%)\end{array}$} & \multirow{2}{*}{$\begin{array}{c}\mathbf{v} \\
\text { (liter) }\end{array}$} & \multicolumn{6}{|c|}{$\Delta \mathbf{H}(\mathbf{m m})$} & \multirow{2}{*}{$\begin{array}{l}\text { Kecepatan } \\
\text { dititik Grid } \\
\text { (m/dtk) }\end{array}$} \\
\hline & & & & $\Delta \mathbf{H}_{1}$ & $\Delta \mathrm{H}_{2}$ & $\Delta \mathbf{H}_{3}$ & $\Delta \mathbf{H}_{4}$ & $\Delta \mathrm{H}_{5}$ & $\mathbf{\Delta H}_{\text {Rata- }}$ & \\
\hline 1 & 1.1 & \multirow{16}{*}{1,5} & \multirow{16}{*}{5} & 2,5 & 2 & 2,4 & 2,5 & 2,4 & 2,36 & 0,215 \\
\hline 2 & 1.2 & & & 2,7 & 2,6 & 2,9 & 2,7 & 2,8 & 2,74 & 0,232 \\
\hline 3 & 1.3 & & & 3 & 2,8 & 2,9 & 3 & 2,8 & 2,9 & 0,239 \\
\hline 4 & 1.4 & & & 2,5 & 2,6 & 2,5 & 2,5 & 2,6 & 2,54 & 0,223 \\
\hline 5 & 2.1 & & & 2,6 & 2,7 & 2,8 & 2,5 & 2,8 & 2,68 & 0,229 \\
\hline 6 & 2.2 & & & 3,3 & 3,1 & 3,3 & 3,5 & 3,4 & 3,32 & 0,255 \\
\hline 7 & 2.3 & & & 3,8 & 3,6 & 3,5 & 3,7 & 3,5 & 3,62 & 0,267 \\
\hline 8 & 2.4 & & & 2,9 & 2,7 & 2,5 & 2,6 & 2,6 & 2,66 & 0,228 \\
\hline 9 & 3.1 & & & 2,6 & 2,5 & 2,5 & 2,8 & 2,7 & 2,62 & 0,227 \\
\hline 10 & 3.2 & & & 3,4 & 3,5 & 3,6 & 3,2 & 3,4 & 3,42 & 0,259 \\
\hline 11 & 3.3 & & & 3,5 & 3,7 & 3,4 & 3,6 & 3,5 & 3,54 & 0,264 \\
\hline 12 & 3.4 & & & 3 & 3,2 & 2,9 & 2,8 & 2,8 & 2,94 & 0,240 \\
\hline 13 & 4.1 & & & 2,7 & 2,8 & 2,7 & 2,6 & 2,7 & 2,7 & 0,230 \\
\hline 14 & 4.2 & & & 3,8 & 3,4 & 3,6 & 3,7 & 3,4 & 3,58 & 0,265 \\
\hline 15 & 4.3 & & & 4,2 & 4,1 & 4,2 & 4,2 & 4,2 & 4,18 & 0,286 \\
\hline 16 & 4.4 & & & 2,4 & 2,3 & 2,5 & 2,5 & 2,4 & 2,42 & 0,218 \\
\hline
\end{tabular}

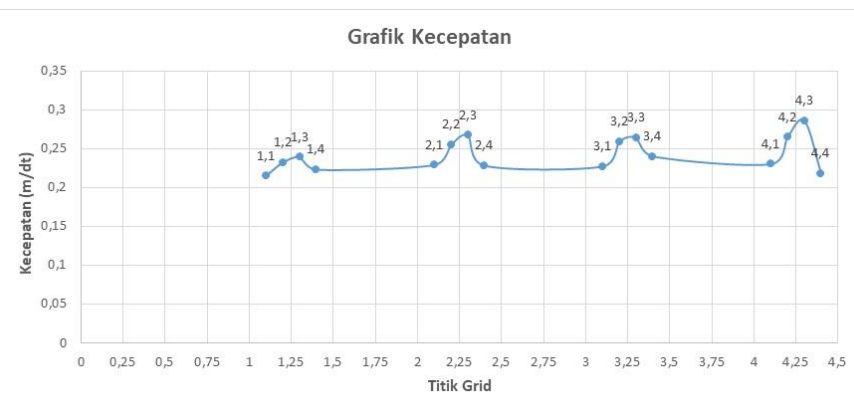

Gambar 9. Grafik kecepatan dasar saluran Kerikil kemiringan $1,5 \%$ 
Dari grafik di atas dapat dilihat bahwa kecepatan aliran air maksimum pada dasar saluran kerikil dengan kemiringan $1,5 \%$ teletak pada titik grid 4.3 dengan kecepatan $0,286 \mathrm{~m} / \mathrm{dtk}$ dengan volume air 5 liter.

\section{c. Kemiringan $2,5 \%$}

Tabel 6. Data hasil pengujian dengan dasar saluran Kerikil

\begin{tabular}{|c|c|c|c|c|c|c|c|c|c|c|}
\hline \multirow[b]{2}{*}{ No } & \multirow{2}{*}{$\begin{array}{l}\text { Titik } \\
\text { Grid }\end{array}$} & \multirow{2}{*}{$\begin{array}{c}\text { Kemiringan } \\
\text { (\%) }\end{array}$} & \multirow{2}{*}{$\begin{array}{c}\mathrm{V} \\
\text { (liter) }\end{array}$} & \multicolumn{6}{|c|}{$\Delta \mathrm{H}(\mathrm{mm})$} & \multirow{2}{*}{$\begin{array}{c}\text { Kecepatan dititik } \\
\text { Grid } \\
\text { (m/dtk) }\end{array}$} \\
\hline & & & & $\Delta \mathbf{H}_{1}$ & $\Delta \mathbf{H}_{2}$ & $\Delta \mathbf{H}_{3}$ & $\Delta \mathbf{H}_{4}$ & $\Delta \mathbf{H}_{5}$ & $\Delta \mathbf{H}_{\text {Rata- }}$ & \\
\hline 1 & 1.1 & \multirow{12}{*}{2,5} & \multirow{12}{*}{5} & 2,7 & 2,8 & 2,6 & 2,8 & 2,7 & 2,72 & 0,231 \\
\hline 2 & 1.1 & & & $\frac{2, r}{3,1}$ & 3 & 3 & $\begin{array}{l}, 0 \\
3,2\end{array}$ & $\begin{array}{l}2,7 \\
3,2\end{array}$ & $\frac{2,21}{3,1}$ & 0,247 \\
\hline 3 & 1.3 & & & 3,6 & 3,7 & 3,7 & $\begin{array}{l}3,2 \\
3,5\end{array}$ & $\begin{array}{l}3,2 \\
3,4\end{array}$ & 3,58 & 0,265 \\
\hline 4 & 1.4 & & & 2,9 & 3 & 2,8 & 2,9 & 2,9 & 2,9 & 0,239 \\
\hline 5 & 2.1 & & & 2,5 & 2,6 & 2,3 & 2,4 & 2,4 & 2,44 & 0,219 \\
\hline $\begin{array}{ll}6 \\
\end{array}$ & $\frac{2.1}{2.2}$ & & & $\frac{2,5}{2,9}$ & 2,9 & \begin{tabular}{|l|}
$2, x$ \\
3,1
\end{tabular} & \begin{tabular}{|l|l}
2,7 \\
3
\end{tabular} & 3 & 2,98 & 0,242 \\
\hline 7 & 2.3 & & & 3,5 & 3,5 & 3,6 & 3,4 & 3,4 & 3,48 & 0,261 \\
\hline 8 & 2.4 & & & 2,7 & 2,8 & 2,7 & 2,6 & 2,8 & 2,72 & 0,231 \\
\hline 9 & 3.1 & & & 2,4 & 2,6 & 2,5 & 2,6 & 2,5 & 2,52 & 0,222 \\
\hline 10 & 3.2 & & & 2,8 & 2,8 & 2,9 & 2,6 & 2,8 & $\frac{2,78}{2,78}$ & 0,234 \\
\hline 11 & 3.3 & & & \begin{tabular}{|l|}
2,0 \\
2,7
\end{tabular} & $\begin{array}{l}2,8 \\
2,8\end{array}$ & 2,9 & $\begin{array}{l}2,8 \\
2,8\end{array}$ & 2,8 & 2,8 & 0,234 \\
\hline 12 & 3.4 & & & \begin{tabular}{|l|}
2,5 \\
\end{tabular} & 2,4 & 2,4 & 2,5 & 2,3 & 2,42 & 0,218 \\
\hline
\end{tabular}

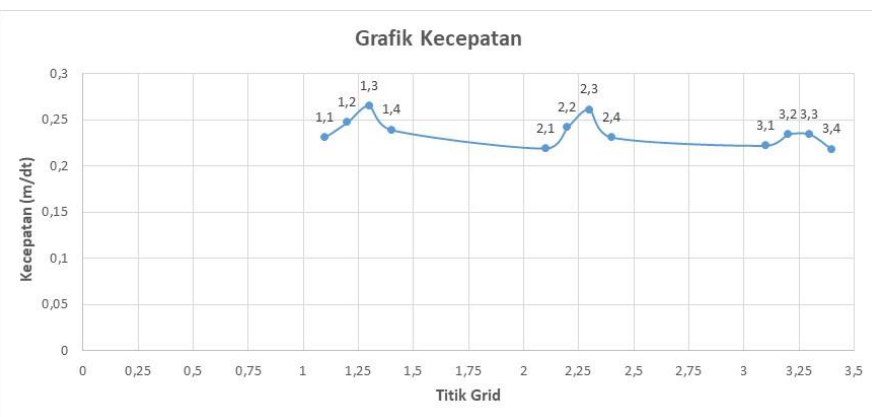

Gambar 9. Grafik kecepatan dasar saluran Kerikil kemiringan $2,5 \%$

Dari grafik di atas dapat dilihat bahwa kecepatan aliran air maksimum pada dasar saluran kerikil dengan kemiringan $0 \%$ teletak pada titik grid 2.3 dengan kecepatan 0,261 m/dtk dengan volume air 5 liter.

\section{Tiga Dimensi Aliran dengan Dasar Beton}

a. Kemiringan $0 \%$

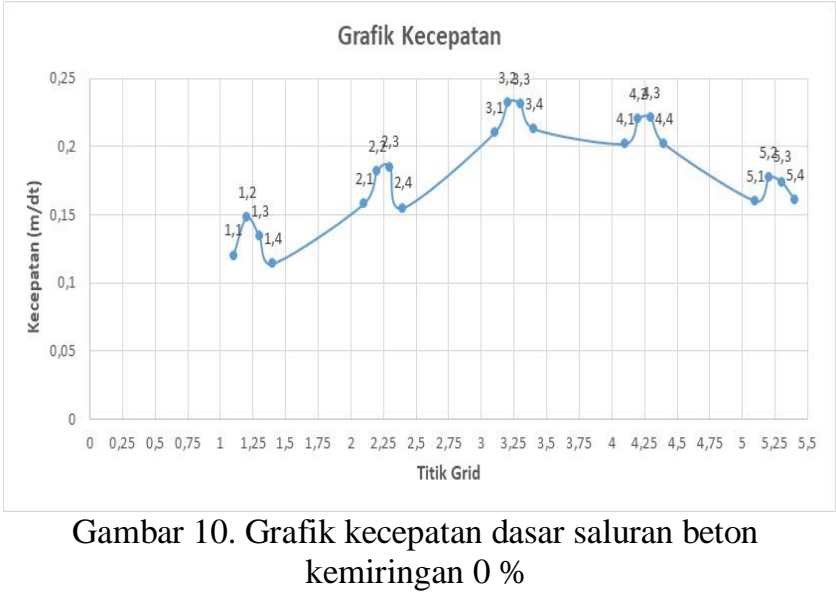

Tabel 7. Data hasil pengujian dengan dasar saluran Beton

\begin{tabular}{|c|c|c|c|c|c|c|c|c|c|c|}
\hline \multirow[b]{2}{*}{ No } & \multirow{2}{*}{$\begin{array}{l}\text { Titik } \\
\text { Grid }\end{array}$} & \multirow{2}{*}{$\begin{array}{c}\text { Kemiringan } \\
(\%)\end{array}$} & \multirow{2}{*}{$\begin{array}{c}\mathbf{v} \\
\text { (liter) }\end{array}$} & \multicolumn{6}{|c|}{$\Delta \mathbf{H}(\mathbf{m m})$} & \multirow{2}{*}{$\begin{array}{c}\text { Kecepatan } \\
\text { dititik Grid } \\
\text { (m/dtk) }\end{array}$} \\
\hline & & & & $\Delta \mathbf{H}_{1}$ & $\Delta \mathbf{H}_{2}$ & $\Delta \mathbf{H}_{3}$ & $\Delta \mathbf{H}_{4}$ & $\Delta \mathbf{H}_{5}$ & $\underset{\substack{\text { rata } \\
\Delta \mathbf{H}_{\text {Rata- }}}}{ }$ & \\
\hline 1 & 1.1 & \multirow{20}{*}{$0 \%$} & \multirow{20}{*}{5} & 0,8 & 0,7 & 0,7 & 0,7 & 0,8 & 0,74 & 0,120 \\
\hline 2 & 1.2 & & & 1,2 & 1,1 & 1 & 1,2 & 1,1 & 1,12 & 0,148 \\
\hline 3 & 1.3 & & & 1 & 0,8 & 0,9 & 0,9 & 1 & 0,92 & 0,134 \\
\hline 4 & 1.4 & & & 0,6 & 0,7 & 0,7 & 0,6 & 0,7 & 0,66 & 0,114 \\
\hline 5 & 2.1 & & & 1,3 & 1,2 & 1,2 & 1,4 & 1,3 & 1,28 & 0,158 \\
\hline 6 & 2.2 & & & 1,7 & 1,6 & 1,7 & 1,8 & 1,6 & 1,68 & 0,182 \\
\hline 7 & 2.3 & & & 1,7 & 1,7 & 1,8 & 1,8 & 1,7 & 1,74 & 0,185 \\
\hline 8 & 2.4 & & & 1,2 & 1,1 & 1,3 & 1,3 & 1,2 & 1,22 & 0,155 \\
\hline 9 & 3.1 & & & 2,3 & 2,2 & 2,2 & 2,2 & 2,3 & 2,24 & 0,210 \\
\hline 10 & 3.2 & & & 2,7 & 2,7 & 2,8 & 2,8 & 2,7 & 2,74 & 0,232 \\
\hline 11 & 3.3 & & & 2,7 & 2,6 & 2,8 & 2,8 & 2,7 & 2,72 & 0,231 \\
\hline 12 & 3.4 & & & 2,3 & 2,4 & 2,3 & 2,4 & 2,2 & 2,32 & 0,213 \\
\hline 13 & 4.1 & & & 2,1 & 2,2 & 2 & 2 & 2,1 & 2,08 & 0,202 \\
\hline 14 & 4.2 & & & 2,4 & 2,6 & 2,5 & 2,4 & 2,4 & 2,46 & 0,220 \\
\hline 15 & 4.3 & & & 2,5 & 2,4 & 2,5 & 2,5 & 2,5 & 2,48 & 0,221 \\
\hline 16 & 4.4 & & & 2,1 & 2 & 2,1 & 2,2 & 2 & 2,08 & 0,202 \\
\hline 17 & 5.1 & & & 1,4 & 1,4 & 1,2 & 1,3 & 1,2 & 1,3 & 0,160 \\
\hline 18 & 5.2 & & & 1,6 & 1,5 & 1,6 & 1,7 & 1,6 & 1,6 & 0,177 \\
\hline 19 & 5.3 & & & 1,5 & 1,5 & 1,6 & 1,6 & 1,5 & 1,54 & 0,174 \\
\hline 20 & 5.4 & & & 1,3 & 1,3 & 1,2 & 1,4 & 1,4 & 1,32 & 0,161 \\
\hline
\end{tabular}

Dari grafik di atas dapat dilihat bahwa kecepatan aliran air maksimum pada dasar saluran beton dengan kemiringan $0 \%$ teletak pada titik grid 4.2 dengan kecepatan 0,264 m/dtk dengan volume air 25 liter. 
b. Kemiringan $1,5 \%$

Tabel 8. Data hasil pengujian dengan dasar saluran Beton

\begin{tabular}{|c|c|c|c|c|c|c|c|c|c|c|}
\hline \multirow[b]{2}{*}{ No } & \multirow[b]{2}{*}{$\begin{array}{l}\text { Titik } \\
\text { Grid }\end{array}$} & \multirow{2}{*}{$\begin{array}{c}\text { Kemiringan } \\
\text { (\%) }\end{array}$} & \multirow{2}{*}{$\begin{array}{c}\mathbf{V} \\
\text { (liter) }\end{array}$} & \multicolumn{6}{|c|}{$\Delta \mathrm{H}(\mathbf{m m})$} & \multirow{2}{*}{$\begin{array}{c}\text { Kecepatan } \\
\text { dititik Grid } \\
\text { (m/dtk) }\end{array}$} \\
\hline & & & & $\Delta \mathbf{H}_{1}$ & $\Delta \mathbf{H}_{2}$ & $\Delta \mathbf{H}_{3}$ & $\Delta \mathbf{H}_{4}$ & $\Delta \mathbf{H}_{5}$ & $\underset{\text { rata }}{\Delta \mathbf{H}_{\text {Rata- }}}$ & \\
\hline 1 & 1.1 & \multirow{12}{*}{1,5} & \multirow{12}{*}{5} & 4,1 & 4 & 4 & 4 & 4,2 & 4,06 & 0,282 \\
\hline 2 & 1.2 & & & 4,7 & 4,8 & 4,9 & 4,6 & \begin{tabular}{|l|}
4,7 \\
\end{tabular} & 4,74 & 0,305 \\
\hline 3 & 1.3 & & & 4,3 & 4,2 & 4,1 & 4,1 & 4,2 & 4,18 & 0,286 \\
\hline 4 & 1.4 & & & 3,5 & 3,4 & 3,5 & 3,4 & 3,4 & 3,44 & 0,260 \\
\hline 5 & 2.1 & & & 3,5 & 3,4 & 3,4 & 3,5 & 3,6 & 3,48 & 0,261 \\
\hline 6 & 2.2 & & & 4,2 & 4,1 & 4 & 4,1 & 4,2 & 4,12 & 0,284 \\
\hline 7 & 2.3 & & & 4 & 3,8 & 4 & 3,8 & 3,9 & 3,9 & 0,277 \\
\hline 8 & 2.4 & & & 3,4 & 3,2 & 3,3 & 3,2 & 2,4 & 3,1 & 0,247 \\
\hline 9 & 3.1 & & & 3,1 & 3 & 2,9 & 2,9 & 2,8 & 2,94 & 0,240 \\
\hline 10 & 3.2 & & & 4 & 3,9 & 3,8 & 3,8 & 4,1 & 3,92 & 0,277 \\
\hline 11 & 3.3 & & & 3,5 & 3,4 & 3,3 & 3,3 & 3,6 & 3,42 & 0,259 \\
\hline 12 & 3.4 & & & 2,3 & 2,1 & 2,2 & 2 & 2,4 & 2,2 & 0,208 \\
\hline
\end{tabular}



Gambar 11. Grafik kecepatan dasar saluran beton kemiringan $1,5 \%$

Dari grafik di atas dapat dilihat bahwa kecepatan aliran air maksimum pada dasar saluran beton dengan kemiringan 1,5\% teletak pada titik grid 1.2 dengan kecepatan $0,305 \mathrm{~m} / \mathrm{dtk}$ dengan volume air 5 liter.

\section{c. Kemiringan $2,5 \%$}

Tabel 9. Data hasil pengujian dengan dasar saluran Beton

\begin{tabular}{|c|c|c|c|c|c|c|c|c|c|c|}
\hline \multirow[b]{2}{*}{ No } & \multirow{2}{*}{$\begin{array}{l}\text { Titik } \\
\text { Grid }\end{array}$} & \multirow{2}{*}{$\begin{array}{c}\text { Kemiringan } \\
(\%)\end{array}$} & \multirow{2}{*}{$\begin{array}{c}\mathbf{v} \\
\text { (liter) }\end{array}$} & \multicolumn{6}{|c|}{$\Delta \mathbf{H}(\mathbf{m m})$} & \multirow{2}{*}{$\begin{array}{c}\text { Kecepatan } \\
\text { dititik Grid } \\
\text { (m/dtk) }\end{array}$} \\
\hline & & & & $\Delta \mathbf{H}_{\mathbf{l}}$ & $\Delta \mathbf{H}_{2}$ & $\Delta \mathbf{H}_{3}$ & $\Delta \mathbf{H}_{4}$ & $\Delta \mathbf{H}_{5}$ & $\begin{array}{c}\Delta \mathbf{H}_{\text {Rata- }} \\
\text { rata }\end{array}$ & \\
\hline 1 & 1.1 & \multirow{8}{*}{2,5} & \multirow{8}{*}{5} & 5 & 4,9 & 5,1 & 4,9 & 5 & 4,98 & 0,313 \\
\hline 2 & 1.2 & & & 6 & 5,9 & 5,9 & 6 & 6 & 5,96 & 0,342 \\
\hline 3 & 1.3 & & & 5,1 & 5,3 & 5,1 & 5,1 & 5,5 & 5,22 & 0,320 \\
\hline 4 & 1.4 & & & 3,9 & 4,2 & 4,2 & 4,2 & 3,9 & 4,08 & 0,283 \\
\hline 5 & 2.1 & & & 3,6 & 3,8 & 3,7 & 3,7 & 3,8 & 3,72 & 0,270 \\
\hline 6 & 2.2 & & & 4,5 & 4,5 & 4,6 & 4,4 & 4,5 & 4,5 & 0,297 \\
\hline 7 & 2.3 & & & 4,3 & 4,2 & 4,4 & 4,3 & 4,1 & 4,26 & 0,289 \\
\hline 8 & 2.4 & & & 3,1 & 3 & 3 & 3 & 3,2 & 3,06 & 0,245 \\
\hline
\end{tabular}

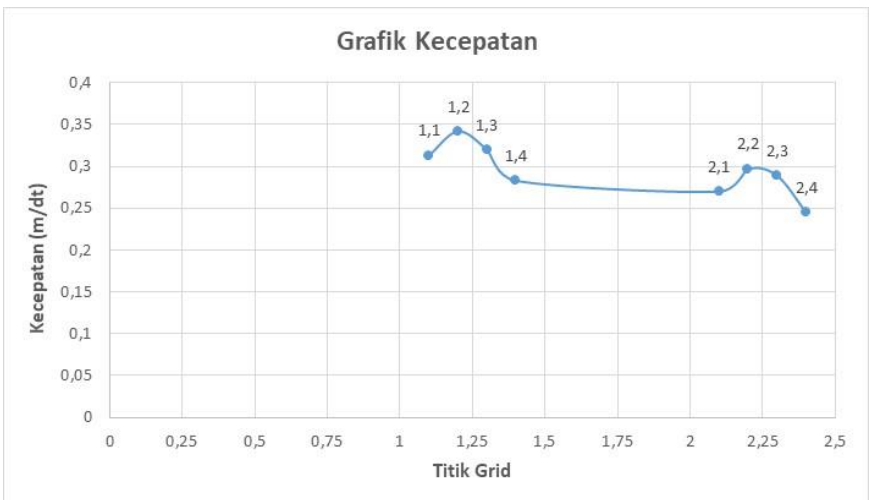

Gambar 12. Grafik kecepatan dasar saluran beton kemiringan 2,5\%

Dari grafik di atas dapat dilihat bahwa kecepatan aliran air maksimum pada dasar saluran beton teletak pada titik grid 1.2 dengan kecepatan $0,342 \mathrm{~m} / \mathrm{dtk}$ dengan volume air 5 liter.

\section{B. Pembahasan}

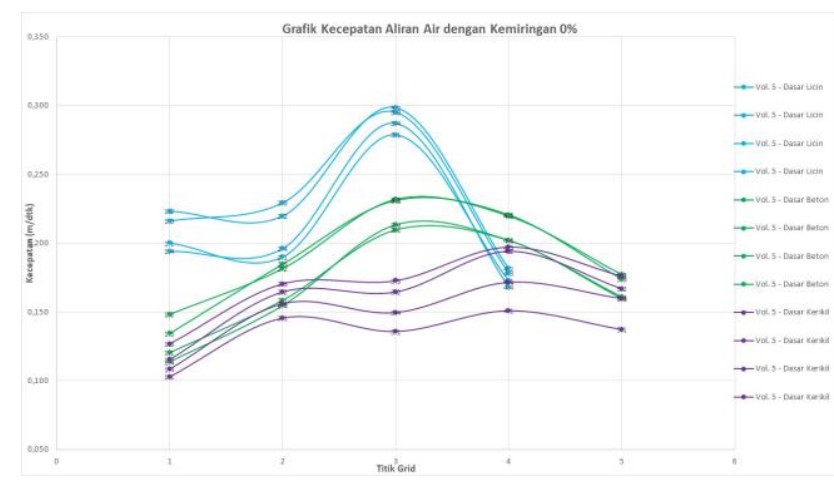

Gambar 13. Grafik Perbandingan Kecepatan Aliran Air Pada Dasar Saluran Licin, kerikil dan beton

Kecepatan aliran air pada suatu saluran sangatlah dipengaruhi oleh kemiringan dan kekasaran saluran tersebut. Untuk perbandingan dari hasil analisis data terhadap variasi kemiringan dan variasi dasar saluran dapat dilihat dan grafik di bawah ini menunjukkan bahwa kecepatan tertinggi terlatak pada saluran dasar licin baik pada kemiringan $0 \%, 1,5 \%$ maupun $2,5 \%$, jadi dapat disimpulkan bahwa semakin kasar dasar saluran maka kecepatan aliran air akan semakin kecil, begitupun sebaliknya. 


\section{Kesimpulan}

Kesimpulan dari hasil penelitian dijelaskan pada bagian ini :

1. Distribusi Kecepatan air dalam flume dalam penampang melintang bervariasi dalam sistem grid.

2. Nilai kecepatan aliran semakin ke atas diperoleh kondisi maksimal pada 0.86d. Sebaliknya, semakin mendekati dasar saluran nilai kecepatan aliran semakin kecil bahkan mendekati nol.

3. Kurva Distribusi kecepatan pada penampang melintang berbentuk parabolik. Ini berarti, semakin mendekati tengah saluran maka semakin besar nilai kecepatan yang diperoleh. Sebaliknya, semakin mendekati tepi saluran maka semakin kecil nilai kecepatan yang diperoleh karena dipengaruhi oleh gaya gesek pada dinding dan dasar saluran.

\section{Ucapan Terima Kasih}

Ucapan terima kasih diberikan kepada Kepala Laboratorium Hidrolika , Ketua Jurusan Teknik Sipil, Teknik Sipil dan Direktur Politeknik Negeri Ujung Pandang serta semua pihak yang mendukung dan memberikan kesempatan untuk melakukan penelitian ini.

\section{Daftar Pustaka}

[1]. Anasiru Triyanti, "Analisis Perubahan Kecepatan Aliran Pada Muara Sungai Palu," Jurnal Smartek Vol.3 No.2, hal $101-112$. 2005, Palu

[2]. Chow Ven Te, Hidrolika saluran Terbuka, alih bahasa E.V. Nensi Rosalia, Penerbit Erlangga, 1989, Jakarta

[3]. Krist, Thomas, "Hidraulika Ringkas dan Jelas," Erlangga, 1989, Jakarta.

[4]. L. Streeter, Victor, "Mekanika Fluida edisi delapan jilid 2," Erlangga. 1986, Jakarta.

[5]. Triadmodjo, Ir. Bambang, "Hidraulika I"., Beta Offset, 1992, Yogyakarta.

[6]. Umar Sri Wahyuni, "Studi Experimen Distribusi Kecepatan Aliran Sungai," Jurnal Tugas Akhir Vol.17, hal 95 -107. 2013, Makassar.

[7]. Wright J.,Steven M.Oslon, Reuben, "Dasar-dasar Mekanika Fluida Teknik Edisi Lima," Penerbit Gramedia Pustaka Utama, 1993, Jakarta 